\title{
GEOGRAPHIC RHYTHM STUDY SCULPTURE AND CARVING ART INDUSTRY JEPARA DISTRICT CASE STUDY IN MULYOHARJO VILLAGE
}

\author{
Angger Bagus Iswanto ${ }^{1}$, Sarwono $^{2}$, Rita Noviani ${ }^{3}$ \\ ${ }^{123}$ Geography Education, Faculty of Teacher Training and Education, \\ Universitas Sebelas Maret Surakarta \\ E-mail: anggerbagus03@gmail.com
}

\begin{abstract}
The purpose of this study is to find out geography rhythm procurement of raw materials, marketing destination, and problems with production factors sculpture and carving industry in the center of the sculpture and carving industry center in Mulyoharjo Village, Jepara District. This study uses a qualitative descriptive method. The respondent is a sculpture and carving industry entrepreneur in Mulyoharjo Village whose population is 104 industries and 30 industries are sampled. Data collection by interview, documentation and observation. Data analysis used a descriptive qualitative interactive model technique. The results of the study concluded that $86.6 \%$ of the industries experienced capital problem, $73.3 \%$ of the industries experiences raw material problem, $66.6 \%$ of the industries experiences marketing problem, and 73,3\% of the industries experiences finding workers problem. The most difficult workforce to find is engraver because absence of engraver regeneration. The raw materials used are teak wood and tamarind. In 1990 the raw material came from Jepara. In 1997-2005 the origin of raw materials expanded into the Java Island region. In 2006-2019 the origin of raw materials moved out of Java. The current availability of wood is not experiencing scarcity but the price is increasing. In 1990-1992 the destination areas for product marketing were in the Jepara Regency area only. In 1993-1995 product marketing could reach big cities in Indonesia. Marketing of products to international markets occurred in 1996 until now. In 2013 the number of exports increased with a value of 7,505,772.91 US \$. In 2014 to 2018 the number of exports decreased.
\end{abstract}

Keywords: Industry, Geography Rhythm, Production Factors.

\section{A. INTRODUCTION}

Indonesia is a country rich in natural resources. Forest is one of the natural resources that plays an important role in life. Forests provide economic, social and ecological benefits. Most Indonesians rely on their lives and make a living from the forest. Indonesia has a large forest area. As we know that forests are covered with trees. The forest has the potential to produce wood which is widely used as building materials, raw materials for making paper, raw materials for furniture industry, raw materials for crafts and so on.

Forests are mostly included in protected areas. Protected areas are the dominant way to ensure biodiversity conservation-nearly $13 \%$ of the earth's surface is located in some form of protected area, and almost $2 \%$ of the ocean - but biodiversity continues to 
decline (Palomo, et al., 2014). Forest areas that are increasingly reduced for industrial needs must be balanced with reforestation. Without forests the people lose income for their daily needs. People are highly dependent on forests and natural resources for their livelihoods and income because of limited employment opportunities and a lack of alternative economic activities (Asare et al., 2013).

Forests that are reduced due to changes in land use caused by many things can change ecosystems. Contexts that have a direct impact on land use decision makers include landscape level factors such as economic restructuring, environmental policy changes, major demographic shifts, and environmental changes (Morzillo et al., 2015). Management of forest potential products is carried out by industry players. Mentioned in Law No. 3 of 2014 concerning Industry that industry is the order and all activities related to industrial activities. Industry is all forms of economic activity that processes raw materials and / or utilizes industrial resources so as to produce goods that have added value or higher benefits, including industrial services. Industry players are people who carry out these industrial activities. Industrial activities are human activities in utilizing existing natural resources. The results of this industrial activity can be used to meet human needs.

Jepara is a district located in the northern coast of Central Java. Like the area in general, Jepara has a distinctive name as the identity of a region, namely the famous Jepara District as the City of Carving. Carving has become the identity of the City of Jepara. Lewis (1966) Identity argument about identity theory creates "identity" as an important field of social science. Besides being important in social sciences, this identity also contributes to the economy in Jepara City. It is this factor that often invites migrants from various regions and even countries, to visit Jepara to get a direct picture of the ability of the Jepara community in terms of carving. Jepara is famous as a place of wood carving industry in the form of carvings and furniture. The superiority of Jepara wood products is mainly in the fine carving and carpentry techniques (Prastiyan, 2017).

Handicraft industry is jor source of employment in most developing countries. The opening of the global market and international trade, handicraft was facilitated and accompanied by the competition of competition as cultural goods (Panda, 2018). The center of the Jepara carving industry is located in the center of the sculpture and carving industry center in the village of 
Mulyoharjo. This sculpture and carving center is a place for home industry and small industry craftsmen. Goods produced by the sculpture and carving industry based on logs and intact roots made with simple machines. Sculpture and carving industry is an industry that produces handicrafts in the form of carvings and sculptures. Sculpture and carving industries are almost scattered throughout the village area of Mulyoharjo Jepara. The industry is a unitary unit between houses, production sites, and marketing stalls (not all) of products originating from home industries (Mundofar, et. al. 2014)

The sculpture and carving industry in Mulyoharjo Village is included in the creative economy. Put simply, the creative economy can be defined as "how people make money with ideas", including the production of creative goods (or creative industries) as well as other related and supporting transaction activities (Howkins, 2001). The term creative industry can be associated with economic activities that use individual creativity, skills and talents, and whose main aspects include intellectual property rights, originality, copyrights and new technologies (for example, Banks \& O'Connor, 2009; Flew \& Cunningham, 2013; Garnham, 2005; O'Connor, 2012). The creative economy is basically built on specific contexts and phenomena found in developed countries, which use the creative economy as a strategy to deal with economic restructuring and also to encourage innovation and growth (Gibson and Homan, 2004).

In 2009 the number of wooden handicraft industries in Mulyoharjo Village reached 355 industrial units, then in 2012 it decreased to only 92 units. In 2015 it increased to 109 units, then the last survey in 2018, the industry totaled 104 units. The number of industrial units experienced a very significant decrease although on the other hand there was an increase in the number but only slightly. This indicates that there are problems in the industry (Disperindag).

The development of carving runs dynamically, with a smooth and stable supply of raw materials. Initially, almost all of the industry's raw material needs were fulfilled by Perhutani. The 19971998 monetary crisis was the beginning of depleting wood raw materials in Jepara. The tightening of the rupiah's low exchange rate has led to increased demand for wood furniture for export. High export market demand, able to be met by craftsmen / entrepreneurs by increasing production capacity.

The monetary crisis that continues to roll into the economic crisis and quickly spread to the political sphere. The 
monetary crisis that continues to roll into the economic crisis and quickly spread to the political sphere. State problems that occur are exploited by individual individuals and groups to clear Perhutani forests together. Looting of the forest is almost without resistance from the authorities. Looted wood is then sold cheaply to craftsmen and furniture entrepreneurs. Looting of Perhutani woods is everywhere until the wood is almost gone. This condition has an impact on the development of the wood working industry and the economy in general in Jepara today. The price of Perhutani wood is expensive because the wood supply is limited (Eskak, Edi. 2013). Now the Jepara wood craft industry is experiencing problems in meeting raw materials, wood prices are increasing every year, so that many SMEs are closing their businesses. The origin of raw materials can change if there is a scarcity of raw materials. Changes in the origin of raw materials in certain years can form the rhythm of raw material procurement.

The destination areas for the marketing of sculpture and carving products in Mulyoharjo Village have changed along with their development. As the sculpture and carving industry in Mulyoharjo Village develops, the range of product marketing will also develop. Changes in marketing objectives can form a rime of marketing objectives. Changes in marketing objectives are accompanied by a number of marketing each year that changes in number.

Exports of wood carving industries in Jepara are unstable. The industry should experience a consistent increase in order to develop. The development of the carving industry in Jepara experienced various problems in its production activities. Disperindag states that the main problems with the pace of development and growth of the industrial and trade sectors in Jepara Regency include: (1) Limited capacity of entrepreneurs which includes financial / capital management, production management and human resources / skilled labor. (2) The number of carved workers is very limited. (3) Lack of awareness of efforts to increase productivity and quality of production. Besides the main problems above, there are also development obstacles which include: (1) Application of technology that is still simple and traditional (2) Not able to produce goods with certain quality standards and is still weak in quality control of production. (3) Limited motivation ability to create new designs. (4) Limited ability in entrepreneurship, management, technology, and capital.

Based on the background of the problem above, the researcher wants to examine how the geographical rhythm of 
raw material procurement, the geography rhythm of the product marketing destination areas and the factors of production that are a problem for entrepreneurs of the sculpture and carving industries in the sculpture and carving industry centers in the Mulyoharjo Village, Jepara District. Edensor (2009) divides geographic rhythm into four namely nature, place, mobilities and bodies. This study does not associate all rhythms to the factors of production because there are rhythms that are considered less related to production activities. This research focuses on two rhythms, namely the procurement of raw materials and mobilities. The geography rhythm of material procurement is not mentioned in the theory put forward by Edensor, but in its understanding the geographical rhythm of raw material procurement has included an understanding of the theory of geographic rhythm.

\section{B. MATERIALS AND METHODS}

This research was conducted in the Village of Mulyoharjo, Jepara District, Jepara Regency. To achieve the first research goal which is to find out the problems faced by sculpture and carving industry entrepreneurs in the Mulyoharjo Village, data were collected through interviews and observations. This qualitative research process involves important efforts, such as asking questions and procedures, collecting specific data from participants, and interpreting the meaning of data (Creswell, 2013: 4). The population is all 104 sculpture and carving industry entrepreneurs. Samples taken as many as 30 entrepreneurs. The data that has been collected is analyzed using the frequency table and described. To achieve the second research objective, which is to know the geographical rhythm of the procurement of raw materials for the sculpture and sculpture industry in the Mulyoharjo Village, data were collected through interviews, observations and documentation. The population is people who know about the sculpture and sculpture industry. Samples were taken as many as 10 people. The collected data were analyzed using qualitative descriptive techniques by providing maps, graphs and tables. To achieve the second research goal, which is to know the geographical rhythm of the product destination areas of the sculpture and sculpture industry in the village of Mulyoharjo, data were collected through interviews, observation and documentation. The population is people who know about the sculpture and sculpture industry. Samples were taken as many as 10 people. The collected data 
were analyzed using qualitative descriptive techniques by providing maps, graphs and tables.

\section{RESULT AND DISCUSSION}

\section{The problem of production factors} in the Mulyoharjo Village Sculpture and Carving Arts Industry.

Since the establishment of the sculpture and carving industry in the village of Mulyoharjo until now experiencing various obstacles in the factors of production. Entrepreneurs or craftsmen of sculpture and carving in Mulyoharjo Village as many as $86.6 \%$ experienced problems with the capital factor. All the industries that have borrowed money in the bank to be used as capital. Before there were as many banks as now, entrepreneurs or craftsmen borrowed money from friends or relatives to use as business capital. The second factor of production is transportation. All industries do not experience problems in terms of transportation. Delivery and shipping forwarding services are now widely available at prices they can reach. As many as $73 \%$ of entrepreneurs or artisans of sculpture and carving have problems in raw material factors. Today's raw materials continue to experience price increases. They hope that the government can take part in controlling the price of raw materials so that they can be reached by industrial entrepreneurs. The number of entrepreneurs or craftsmen who experience problems in marketing is $66.6 \%$. The problem that entrepreneurs often face is licensing problems when they want to send products abroad or outside Java. Employers hope that the government can simplify the licensing process. As many as $83.3 \%$ of industries experience problems in the labor factor. Carvering power is very rare now. The absence of regeneration is one cause of the scarcity of carvers. Entrepreneurs or artisans of the sculpture and sculpture industry hope that the younger generation will continue to struggle to maintain Jepara's identity as a carving city.

\section{Geography Rhythm of Provision of} Raw Materials

The sculpture and carving industry in Mulyoharjo Village began to emerge in 1990. The raw materials used by the sculpture and carving industry in the Mulyoharjo Village are teak and tamarind. Based on the analysis of the geographic rhythm of the material supply, 3 periods of distribution of teak wood and 2 
periods of distribution of tamarind wood. The existence of raw materials is influenced by the looting of woods in 1998. The availability of raw materials which has influenced the existence of sculpture and carving industries in Mulyoharjo Village. When raw materials are abundant, the price of raw materials becomes cheap so that it can increase the income of the sculpture and carving industry entrepreneurs. Along with the development of the industry the origin of raw materials is undergoing changes that are increasingly farther away. The price of raw materials has increased so that it is a problem that must be faced by the industry. The following is a map of the distribution of raw materials and a map of the sculpture and sculpture industry from 1990 to 2019.

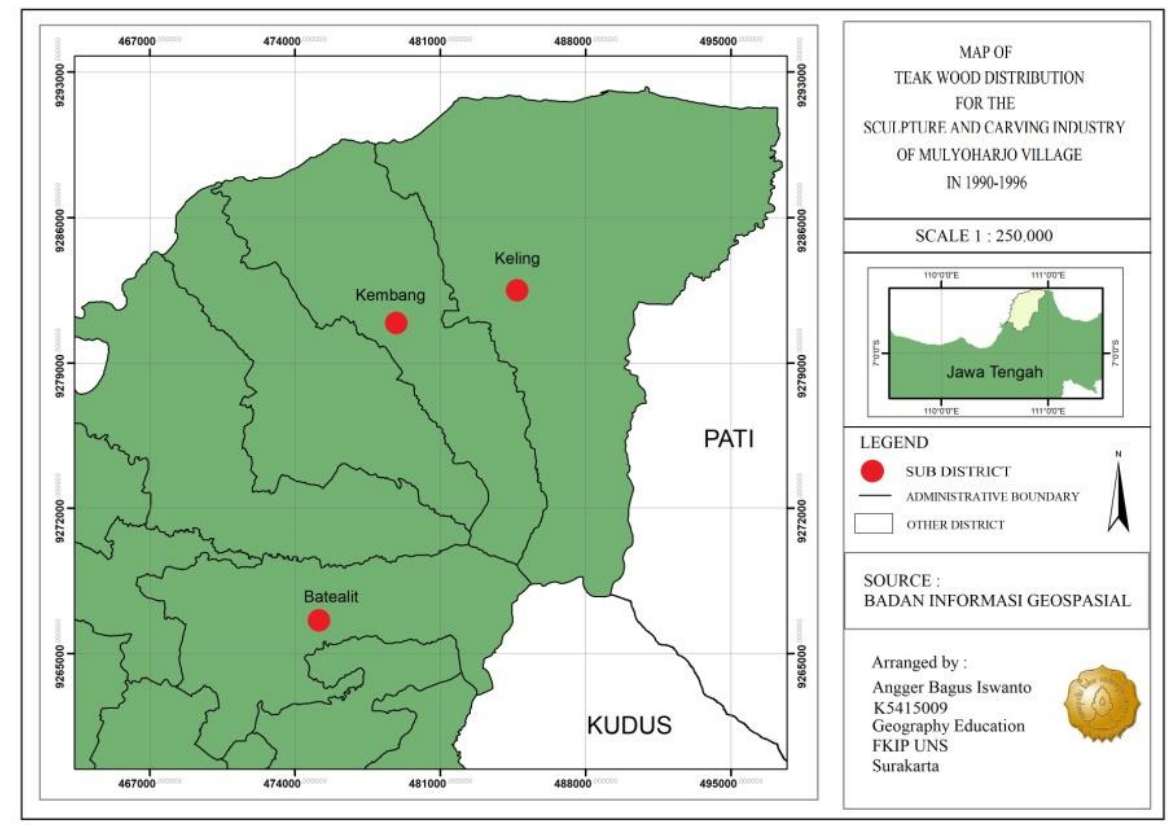

Figure 1. Map of teak wood distribution for the sculpture and carving industry of Mulyoharjo Village in 1990-1996

In 1990-1996 the area of origin of raw materials in the form of teak wood was only in Jepara Regency because there were not many industrial needs so that the raw materials in Jepara Regency could meet the industry's needs. the price of raw materials at that time was low enough that raw materials were not yet a problem for the sculpture and carving industry in the Mulyoharjo Village. 


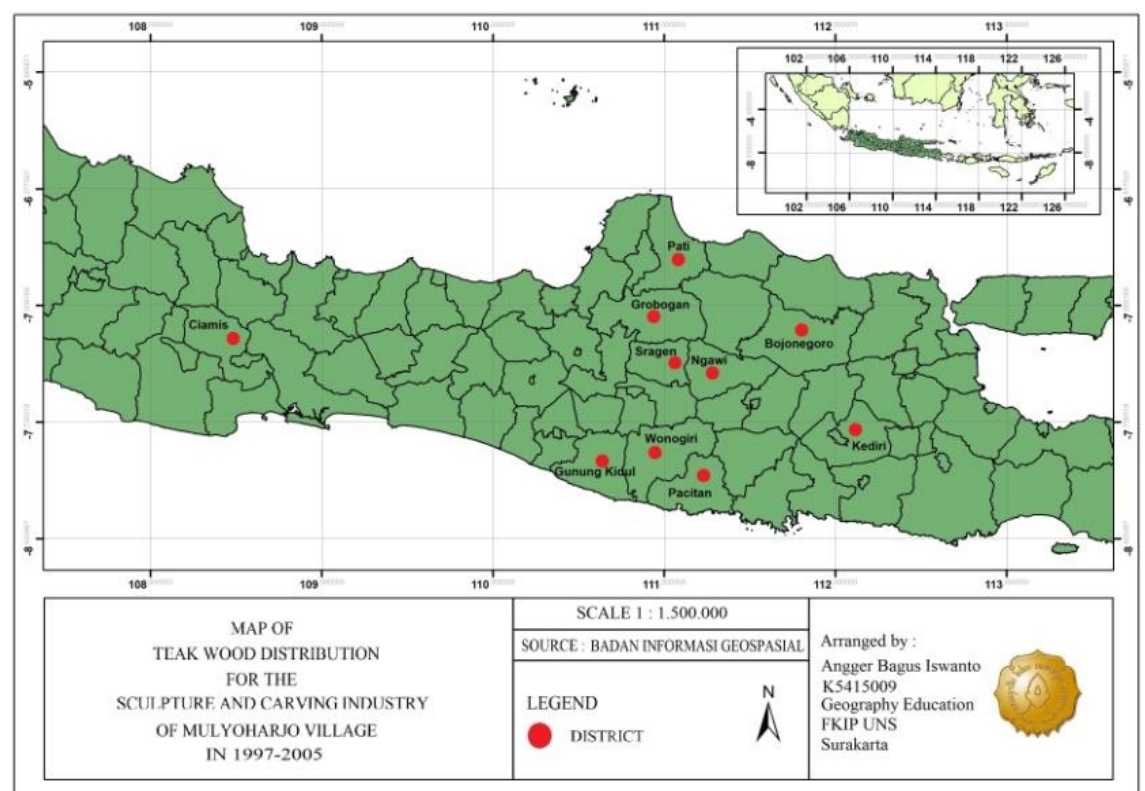

Figure 2. Map of teak wood distribution for the sculpture and carving industry of Mulyoharjo Village in 1997-2005

In 1997-2005 the distribution of origin areas of raw materials in Java. the raw materials that adan in Jepara Regency cannot meet the needs of the sculpture and carving industry because the industry needs are increasing. In addition, because of the looting in 1998, the timber in Jepara was used up. Teak wood from outside Jepara Regency began to enter. The price of wood in 1998 was uncertain because there was a lot of illegal timber circulating as a result of looting.

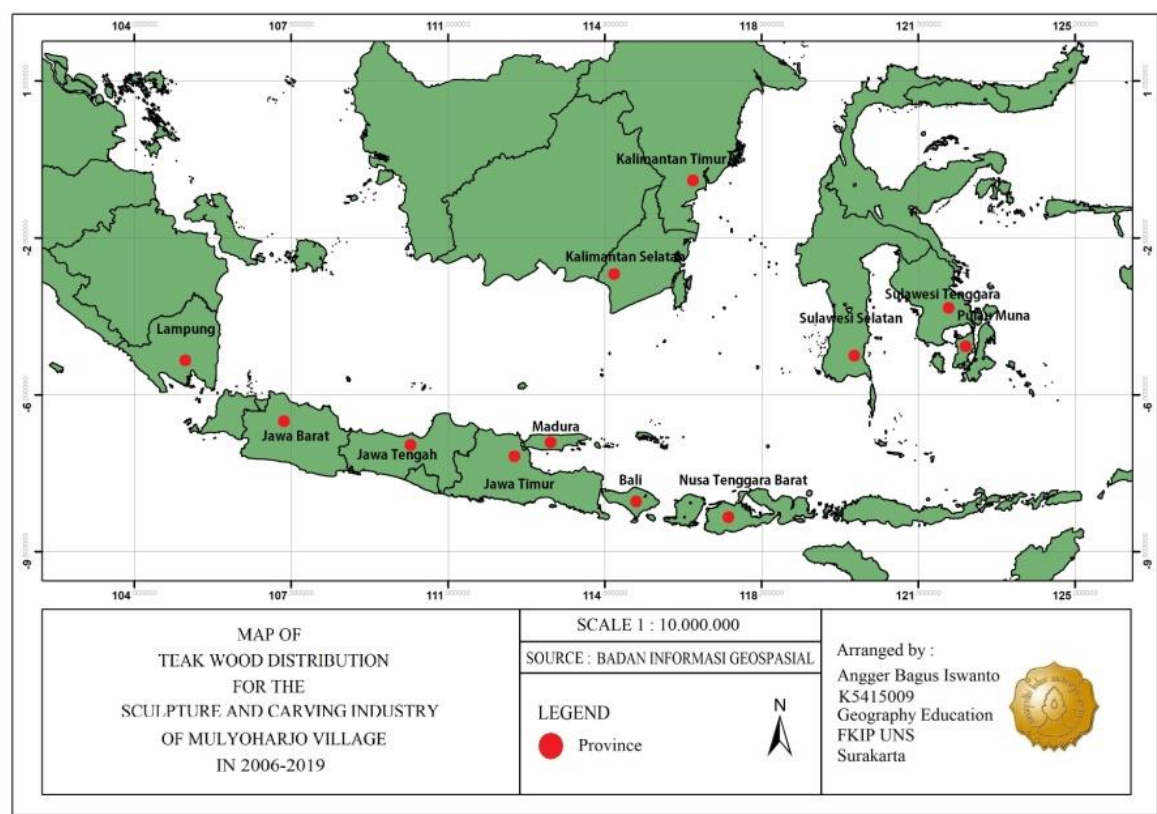

Figure 3. Map of teak wood distribution for the sculpture and carving industry of Mulyoharjo Village in 2006-2019 
In 2006 to 2019 the distribution of the origin of teak wood used by the sculpture and carving industry in the village of Mulyoharjo had spread beyond Java. This is caused by the price of teak wood on the island of Java has increased prices and wood from outside the island of Java is cheaper so that many entrepreneurs choose teak wood from outside the island of Java even though the quality of the wood is lower. The high price of raw materials has become a problem for entrepreneurs.

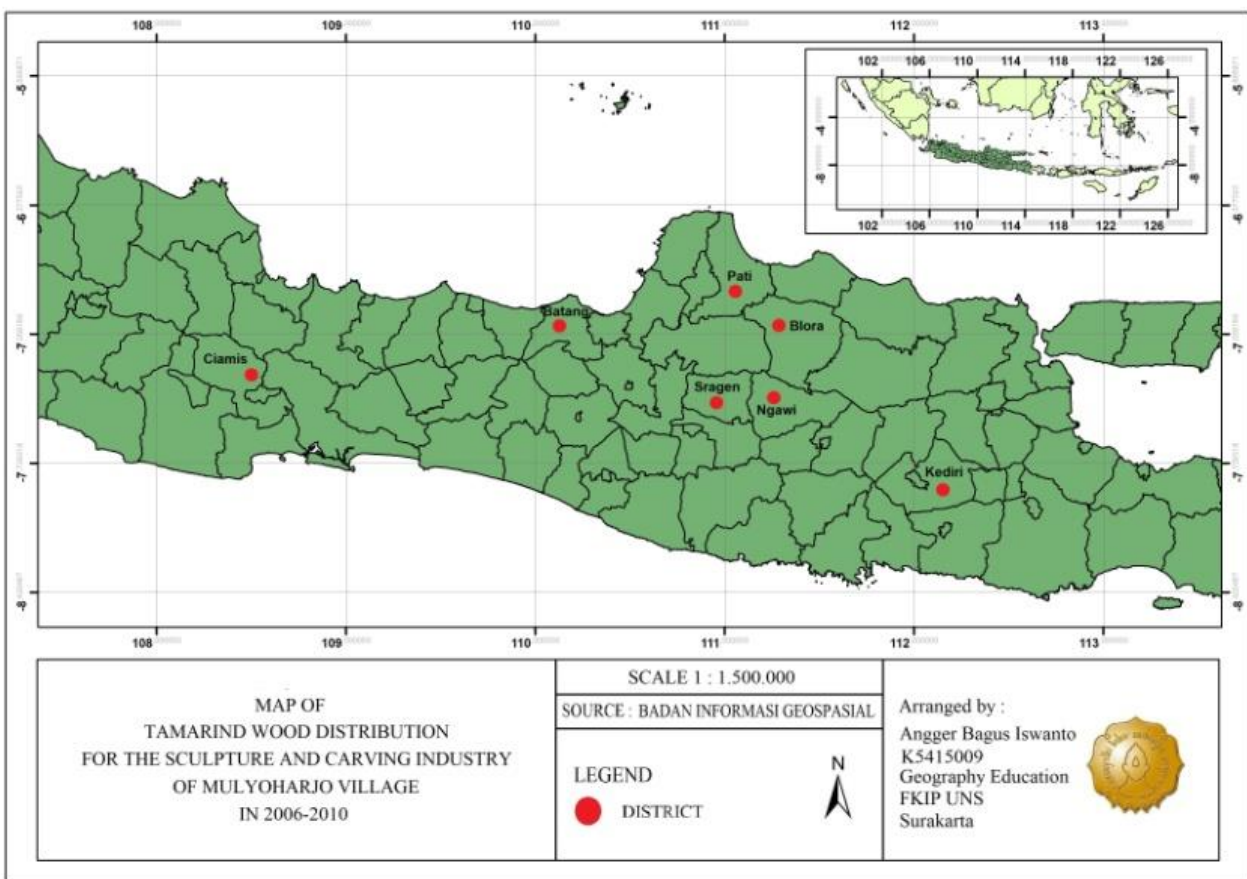

Figure 4. Map of tamarind wood distribution for the sculpture and carving industry of Mulyoharjo Village in 2006-2010

In 2006-2010 the distribution of the area of origin of raw materials in the form of tamarind wood was spread across Java. Entrepreneurs started using tamarind wood as a substitute for teak wood since 2006. The price of tamarind wood is cheaper than teak wood. The tamarind wood pattern is almost the same as teak wood. Trembesi wood is usually used to produce local products while teak wood for imported products. 


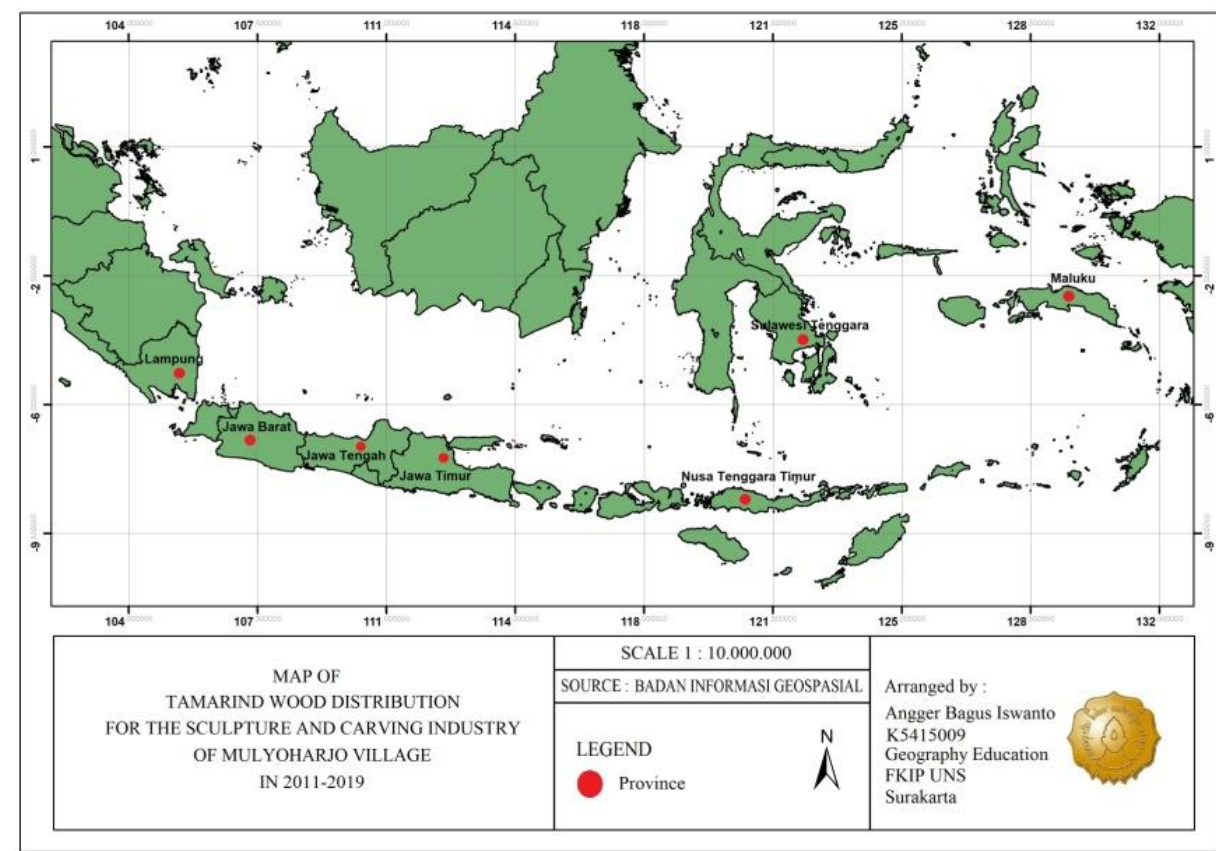

Figure 5. Map of tamarind wood distribution for the sculpture and carving industry of Mulyoharjo Village in 2011-2019

In 2011-2019 the origin of raw materials in the form of tamarind wood came from outside Java. This is due to the fact that the tamarind wood in Java has increased in price so that entrepreneurs look for tamarind wood outside Java which is cheaper. However, tamarind wood originating from Java Island has better quality than wood originating from outside Java Island.

\section{Rhythm of the Geography of the Purpose of Marketing}

The destination areas for marketing carving and carving industry products in the Mulyoharjo
Village from 1990 to now have increased to be able to penetrate the international market in 1996. In the early 1990s the marketing of products was only in the downtown area. In 1993 marketing began to spread to major cities in Indonesia so that sculpture and carving products could be glimpsed by the international market. The amount of export marketing from 2010-2019 is unstable. The following is a map of the destination areas for marketing carving and carving industry products in Mulyoharjo Village from 19932019. 


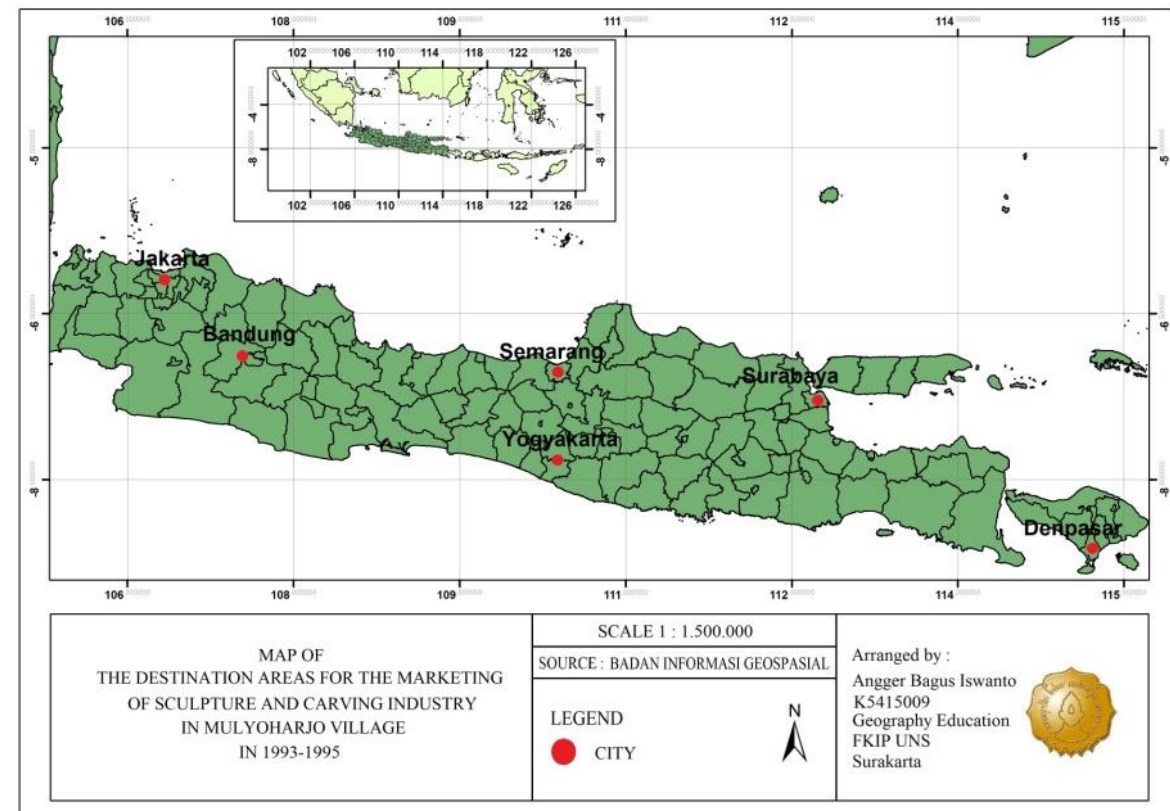

Figure 6. Map of the destination areas for the marketing of sculpture and carving industries in Mulyoharjo Village in 1993-1995

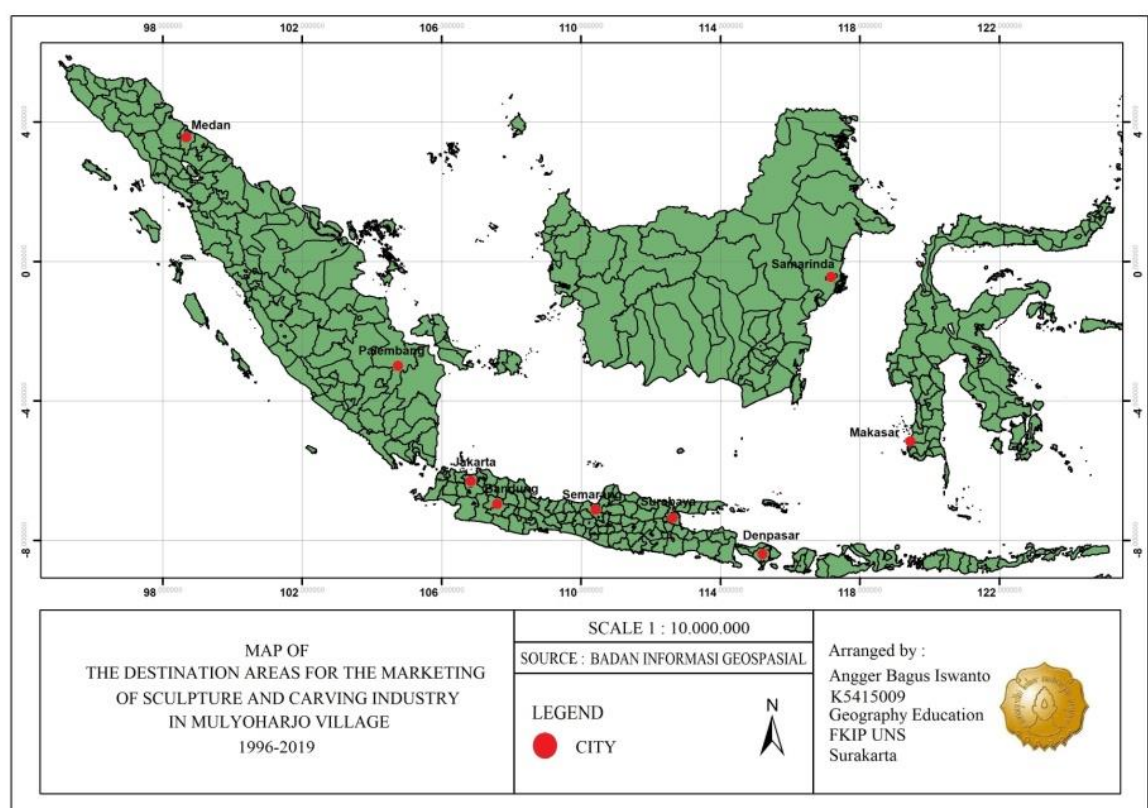

Figure 7. Map of the destination areas for the marketing of sculpture and carving industries in Mulyoharjo Village in 1996-2019

\section{CONCLUSIONS}

1. Factors that are a problem for the development of the carving and carving industry in the central area of the carving and carving industry in the village of Mulyoharjo are capital factors, raw material factors, marketing factors and labor factors. The most problem faced by entrepreneurs in the sculpture and carving industry in the village of Mulyoharjo is the problem of capital 
factors. $86.6 \%$ of industries experience capital problems. the factor that is not a problem is the transportation factor, because all industries do not experience problems with transportation factors.

2. The location of raw materials used by industry in the central area of the sculpture and carving industries in Mulyoharjo Village, Jepara Regency has changed its location from 1990 to the present. The raw materials used are teak and tamarind. the area of origin of the raw material was initially in Jepara Regency then in 1996 the origin of the raw material spread in Java. In 2005 to 2019 raw materials came from outside Java. Raw material prices always increase.

3. The marketing objectives of the products produced by the Mulyoharjo Village sculpture and carving industry have changed the marketing reach from 1990 to the present. In 1990-1992 marketing was only in Jepara Regency, in 1993-1995 product marketing had reached Java and Bali. The sculpture and carving industry began to export in 1996 to 2019. The export marketing of handicraft and wood products in Jepara Regency in 2013 the number of exports increased with a value of US $\$ 7,507,772.91$ in 2014 . In the following year until 2019 the number of exports was unstable.

\section{E. REFERENCES}

Asare R A., Kyei A., \& Mason, J J. 2013. The community resource management area mechanism: a strategy to manage African forest resources. Philosophical Transactions of The Royal Society $B$, Vol 368 Issue 1625 pg 1-9. https://doi.org/10.1098/ rstb.2012.0311

Banks, M \& O’Connor, J. 2009. After the creative industries. International Journal of Cultural Policy, Vol 15 Issue 4, Pg 365373.

Creswell, John W. 2013. Research Design. Terjemah, Achmad Fawaid. Yogyakarta: Pustaka Pelajar.

Dinas Perindustrian dan Perdagangan Kabupaten Jepara. 2019.

Edensor, Tim. 2009. Geography of Rhytm : Nature, Place, Mobilities, and Bodies. United Kingdom: MPG Group Books.

Eskak, Edi. 2013. Krisis Bahan Baku Seni Kerajinan Kayu Di Jepara Dan Solusi Pemecahannya. Dinamika Kerajinan dan Batik, Vol 30 (2), hal. 73-84

Flew, T dan Cunningham, S. 2010. Creative Industries after the First Decade of Debate. The Information Society, 26 (2), pg. 113-123.

Garnham, N. 2005. From cultural to creative industries: An analysis of the implications of the 'creative industries' approach to arts and media policy making in the United Kingdom. International 
Journal of Cultural Policy, Vol 11 Issue 1, pg. 15-29.

Gibson, C dan Homan, S. 2004. Urban Redevelopment, Live Music and Public Space: Cultural performance and the re-making of Marrickville. International Journal of Cultural Policy, Vol 10 (1), pg. 67-84.

Howkins, J. 2001. The Creative Economy: How People make Money from Ideas. London: Penguin Press.

Lewis, D K. 1966. An argument for identity theory. The Journal of Philosophy, Vol 63 (1) pg. 17-25.

Lussault, M. 2003. The Sense Of Movement: Modernity and Mobilities in Contemporary Urban Societies. Paris: Centre culturel international de CerisylaSalle, Institute pour la ville en mouvement.

Morzillo, A T., et, al. (2015). "Communities in the middle": Interactions between drivers of change and place-based characteristics in rural forestbased communities. Journal of Rural Studies, Vol 42, pg. 79 -90.
Mundofar, et. al. 2014. Penataan Koridor Sentra Industri Patung Dan Ukir Desa Mulyoharjo Jepara. Skripsi. Semarang: UNDIP.

O'Connor, J. 2012. Surrender to the Void: Life after Creative Industries. Cultural Studies Review, Vol 18 (3), pg. 388-410.

Palomo I, et. al. 2014. Incorporating the social-ecological approach in protected areas in the Anthropocene. BioScience, Vol 64 Issue 3, pg. 181-191.

Panda, D K. 2019. Role of Identity In The Business Ecosystem: An Inquiry In Indian Stone Carving Clusters. International Journal of Organizational Analysis, Vol 27 (4), pg. 1168-1190.

Prastiyan, Damas. 2009. Dinamika Industri Seni Ukir Jepara 19892009. Jurnal Risalah, Vol 4 (5).

Undang-Undang Nomor 3 Tahun 2014 tentang Perindustrian. 